\title{
Ectohydrolase activity in surface waters of the Hudson River and western Long Island Sound estuaries
}

\author{
Gordon T. Taylor*, Juliette Way, Ying Yu, Mary I. Scranton \\ Marine Sciences Research Center, Stony Brook University, Stony Brook, New York 11794-5000, USA
}

\begin{abstract}
Variability in hydrolytic ectoenzyme activity was investigated at 3 stations along the salinity gradient of the Hudson River estuary and at 1 station in western Long Island Sound between October 1996 and October 1998. Activities of aminopeptidase, $\beta$-glucosidase, chitinase, lipase and alkaline phosphatase were estimated at each station using fluorogenic substrate analogs (methylumbelliferyl [MUF]- and methylcoumarinylamide [MCA]-labeled). Potential hydrolysis rate constants for these ectohydrolases varied widely over time and among stations; from $<0.01$ to $90 \% \mathrm{~d}^{-1}$. Most rate constants were highest in July and August. However, temperature only weakly correlated with activities of 4 of the 5 ectohydrolases in the Hudson River $(\mathrm{r}=0.35-0.58, \bar{x}=0.42)$ and was not significantly correlated with activity of any ectohydrolase in Long Island Sound. Activities of most ectohydrolases varied independently of dissolved and particulate organic carbon, bacterial abundance, chlorophyll $a$ and primary production. Aminopeptidase activity was strongly correlated with bacterial production $(\mathrm{r}=0.78-0.89 ; \mathrm{p}<0.0001 ; \mathrm{n}=46)$ and negatively with total inorganic nitrogen concentration $(\mathrm{r}=-0.57 ; \mathrm{p}<0.0001 ; \mathrm{n}=47)$ among all stations. However, each station had distinct enzyme activity profiles, suggesting acclimation of bacterial communities to different nutritional regimes. For example, alkaline phosphatase and aminopeptidase activity dominated the oligohaline station, while at the marine station, activity was more evenly divided among all ectohydrolases but lipase. Activities of aminopeptidase, $\beta$-glucosidase and chitinase were highly correlated with turnover of ${ }^{3} \mathrm{H}$-leucine, ${ }^{14} \mathrm{C}$-glucose and ${ }^{14} \mathrm{C}$-acetate, suggesting a close coupling between hydrolysis of polymeric source materials and consumption of a variety of monomeric products.
\end{abstract}

KEY WORDS: Ectoenzymes · Hydrolysis · Bacterioplankton · Organic matter · Estuaries

\section{INTRODUCTION}

The identity and provenance of dissolved organic carbon (DOC) supporting the high bacterial biomass and activity observed in most estuaries are poorly known, because these pools are complex, dynamic and technically difficult to characterize. A significant fraction $(<20$ to $35 \%)$ of DOC consists of high molecular weight polymeric compounds, such as proteins, lipids, nucleic acids, and polysaccharides (Whitehouse et al. 1989, Amon \& Benner 1994, Guo et al. 1994, Dai et al. 1995). Results from a few laboratory studies have suggested that biogenic polymers can be very labile (Hollibaugh \& Azam 1983, Tranvik 1990), which has been confirmed in field studies in the Gulf of Mexico and Amazon River plume (Benner et al. 1995, Amon \& Benner 1996). If true in other aquatic settings, polymeric substrates may be more important to bacterial metabolism than previously appreciated.

Allochthonous input of organic matter contributes significant energy subsidies to bacterioplanktonic metabolism in rivers and estuaries beyond that supported by autochthonous production (Kempe 1984, Smith \& Mackenzie 1987, Findlay et al. 1991). In the York River estuary (Virginia, USA), for example, as little as $8 \%$ of natural DOC entering the estuary was remineralized within a month (Raymond \& Bauer 2000). In the freshwater Hudson River, an estimated $69 \%$ of the total 
organic matter pool originates from the upland watershed and the remainder from autochthonous production by phytoplankton and aquatic macrophytes (Howarth et al. 1996). Approximately $59 \%$ of this pool is remineralized by plankton ( $54 \%$ ) or deposited in sediments ( $5 \%$ ) in the tidal portion of the river, between Troy Dam $(\mathrm{rkm}=$ river kilometer measured from the southern tip of Manhattan Island [248]) and Newburgh, NY (rkm 100). Much of the remaining $41 \%$ enters the estuary and presumably supports little bacterial growth because most of this material is refractory after passing through soil and riverine systems (Taylor et al. 2003).

Within the saline portion of the Hudson River estuary, aged organic matter from upriver mixes with relatively young carbon contributed by the estuary's modest primary production and that derived from a highly urbanized watershed (Taylor et al. 2003). Colloidal organic matter appears to be removed along the Hudson salinity gradient while low-molecular weight DOC (LMW-DOC) appears to be added (Sañudo-Wilhelmy \& Taylor 1999). Such behavior can be explained by preferential consumption of colloids relative to LMWDOC, cycling between these phases or multiple inputs of material to the estuary. The strong correlation observed between bacterial growth and colloidal organic carbon (OC) concentrations is consistent with colloidal depletion being biologically mediated. However, the identity and lability of colloids and how these vary within the estuary are unknown.

Colloids and polymeric organic matter in aquatic systems must first be hydrolyzed by ectoenzymes to monomers or oligomers to permit transport across cell membranes (Hoppe 1983, Chróst et al. 1989). In fact, production of low molecular weight compounds via ectohydrolase activity may be the rate-limiting step for bacterial production in most aquatic ecosystems (Hoppe et al. 1988). By examining patterns of ectohydrolase activity and monomer turnover, one can deduce which classes of compounds are important to bacterial community metabolism at the time of sampling. However, hydrolysis of macromolecules to labile LMW-DOC has received limited study in estuaries.

The present study utilized fluorogenic analogs to examine the potential activities of 5 classes of ectohydrolases and to assess their temporal and spatial patterns within 2 interconnected but functionally distinct estuaries, the lower Hudson River and western Long Island Sound. Patterns of enzyme activity were used to evaluate the role of classes of biogenic polymers (proteins, polysaccharides, chitin, lipids and organophosphorus compounds) in fueling bacterial production. Individual ectohydrolase activities were also compared to environmental variables, uptake of monomeric substrates, bacterial production and inorganic nutrient concentrations.

\section{MATERIALS AND METHODS}

Site description. The Hudson is a shallow, temperate estuary whose surface waters are influenced by allochthonous inputs of organic matter from terrestrial runoff, point source discharges and a few marshes and wetlands upriver (Findlay et al. 1998). Estimates of freshwater residence times vary from as low as $0.1-4 \mathrm{~d}$ within the narrow, oligohaline segment (Howarth et al. 2000) to 15-60 d in the wider, mesohaline portion (Clark et al. 1992). In contrast, western Long Island Sound has relatively long hydrologic residence times (63-166 d; Turekian et al. 1996), receives most of its freshwater through sewage treatment discharges, and thereby is not as heavily influenced by river discharge as the Hudson.

We sampled 3 stations in the Hudson River estuary and one within western Long Island Sound (Fig. 1). Stations in the Hudson lie along the salinity gradient. Haverstraw Bay (HB) lies in the widest section of the river $(\sim 4 \mathrm{~km})$ and usually marks the limit of the salt intrusion. At this site, waters are well-mixed from surface to bottom (Taylor et al. 2003). The second station, Grant's Tomb (GT), is located within the salt wedge. This station is immediately seaward of the largest municipal sewage discharge $\left(6.4 \times 10^{5} \mathrm{~m}^{3} \mathrm{~d}^{-1}\right)$ in the Hudson, the North River water pollution control plant. The third station is just north of the Verrazano Narrows Bridge (VN) and can usually be characterized as marine. The western Long Island Sound station is located at Execution Rocks (ER). In contrast to the Hudson stations, waters in this area are strongly stratified, clearer and support relatively high primary productivity (Taylor et al. 2003). Bottom waters in western Long Island Sound exchange slowly and are subject to seasonal hypoxia (see Anderson \& Taylor 2001).

Sampling. Sampling was conducted on twelve $3 \mathrm{~d}$ cruises between October 1996 and October 1998. All cruises were performed aboard the Marine Science Research Center's research vessel, RV 'Onrust'. Logistical limitations (ship scheduling, transit times, etc.) prohibited sampling of all stations during the same tidal phase. Stns HB, GT and VN were consistently sampled near dawn and ER was sampled in late morning. Profiles of $\mathrm{T}, \mathrm{S}$ and $\mathrm{O}_{2}$ were obtained using a General Oceanics sampling rosette instrumented with an Applied Micro Systems (AMS) CTD package and YSI oxygen electrode to define the surface mixed layer, pycnocline and bottom waters. For this study, water samples from the surface mixed layer were acquired using four 5-1 Niskin bottles. Samples were pooled in a 221 Cubitainer $^{\circledR}$ (Hedwin) and mixed well to minimize settling of particles before dispensing to separate 2.51 polycarbonate bottles. Pooling of samples was necessary to accommodate the large array of analyses performed, only a subset of which are presented here (see Taylor et al. 2003). 


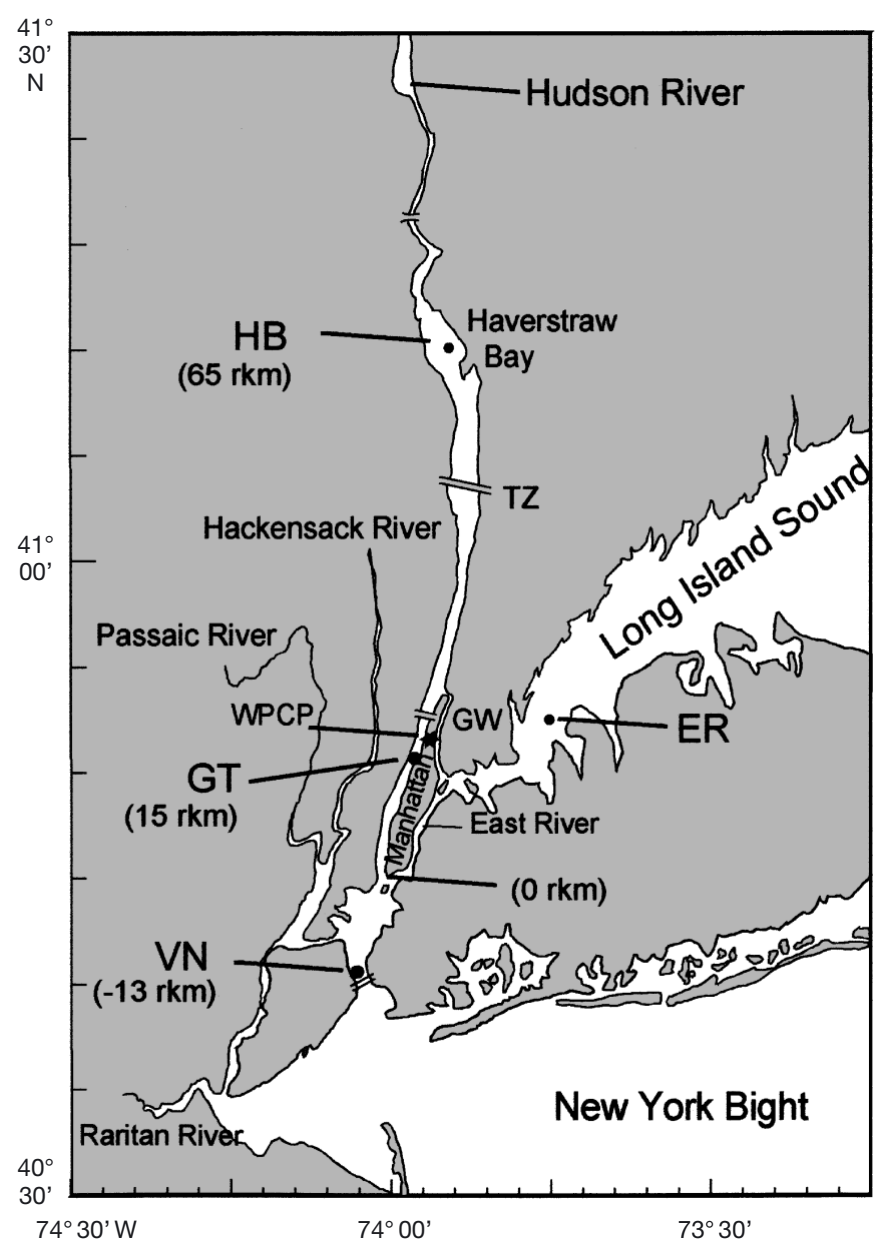

Fig. 1. Map of study site in the lower Hudson River estuary, NY/NJ Harbor complex and Long Island Sound estuary. Sampling stations: Haverstraw Bay (HB), $41^{\circ} 13.27^{\prime} \mathrm{N}$,

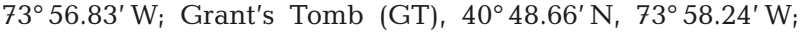
Verrazano Narrows (VN), $40^{\circ} 36.81^{\prime} \mathrm{N}, 74^{\circ} 03.47^{\prime} \mathrm{W}$; and Exe-

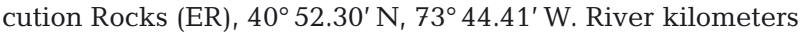
$(\mathrm{rkm})$ are relative to the Battery at the southern tip of Manhattan. TZ: Tappan Zee bridge; GW: George Washington bridge; WPCP: North River water pollution control plant

Preparation of model substrates. Six fluorogenic substrate analogs were selected to assay activities of ectohydrolases acting on 5 major classes of macromolecules present in natural waters; leucine-methylcoumarinylamide (leu-MCA) for proteins, methylumbelliferyl $\beta$-D-glucoside (MUF-gluc) for cellulose, MUF-N-acetyl$\beta$-D-glucosaminide (MUF-chi) for chitin, MUF-acetate (MUF-ace) and MUF-palmitate (MUF-palm) for lipids, and MUF-phosphate (MUF-phos) for phosphate-bearing organics. Results from MUF-ace assays are not presented (reasons discussed below). Solutions $(500 \mu \mathrm{M})$ of substrate analogs were prepared in 10:1 sterile water:methylcellosolve solutions to promote complete dissolution (Hoppe 1993). The methylcellosolve was omitted for MUF-phos, which dissolved readily in water alone. Effects of methylcellosolve on enzymatic activities have been tested previously and appear to be negligible (Hoppe 1983). Working solutions were stored frozen until needed.

Ectohydrolase activity assays. At each station, 5 or 6 fluorogenic analogs were added to separate surface water samples in $15 \mathrm{ml}$ polystyrene centrifuge tubes immediately after collection. Conducting kinetics experiments with a range of concentrations for each tracer as suggested by Hoppe (1993) was not feasible because of the number of samples generated in the field. Furthermore, measurements of ambient substrate concentrations were beyond the scope of this study. Therefore, a final concentration of $20 \mu \mathrm{M}$ was selected using the best available information on saturating levels in coastal waters (Hoppe 1983, Chróst \& Velimirov 1991, Karner \& Herndl 1992, Martinez et al. 1996). This concentration was intended to saturate enzyme systems with substrate analog to estimate maximum hydrolysis velocities, $V_{\max }\left(\mu \mathrm{M} \mathrm{d}^{-1}\right)$ (Chróst \& Velimirov 1991).

Subsequent kinetics experiments conducted with leu-MCA and MUF-phos at these stations demonstrated that $20 \mu \mathrm{M}$ was always in the first-order portion of the response curve and suggested it was closer to the half-saturation constant $\left(K_{\mathrm{m}}\right)$ than to the saturating concentrations that occurred above $100 \mu \mathrm{M}$ in some samples (Way 2000). Furthermore, competition experiments with samples from our study sites confirmed that fluorogenic analogs effectively mimic selected natural substrates. For example, additions of phosphogluconic acid effectively depressed apparent hydrolysis of $20 \mu \mathrm{M}$ MUF-phos. Likewise, ribulose-1,5-bisphosphate carboxylase/oxygenase and chitin competed with leu-MCA and MUF-chi, respectively (Way 2000). Therefore, hydrolysis derived from near-tracer levels of fluorogenic analog was used to estimate the potential turnover rate $\left(H_{\mathrm{r}}=\% \mathrm{~d}^{-1}\right)$ of a given class of polymers (Hoppe et al. 1993).

Incubations were conducted in darkness at ambient temperature in a flow-through water bath on deck. Fluorescence was measured on a Shimadzu RF-551 Fluorescence HPLC monitor over $10 \mathrm{~h}$ time courses. Linearity of time courses suggests that the incubation period was short enough to minimize acclimation of communities to added substrate. Substrate depletion was rarely indicated, because $<5 \%$ of the tracer was usually consumed by the end of the experiment. Control samples at each station were boiled in a microwave oven and cooled. Individual control samples were amended with fluorogenic analogs and incubated under the same conditions as live samples. 
To calibrate the fluorescence response and compensate for varying background fluorescence among samples, $20 \mu$ internal standards of $5 \mu \mathrm{M}$ MUF or MCA were repetitively added to the appropriate samples at the final time points for each station and fluorescence recorded. Calibration curves were generated for both fluorochromes (MUF, MCA) by regressing fluorochrome concentrations against fluorescence. Hydrolysate production rates were calculated from linear regressions of fluorochrome release over a minimum of 4 time points $\left(r^{2}>0.90\right)$ and the slope's standard error was used to assess precision of the estimate. The average relative standard error for rate estimates was $\sim 14 \%$ of the mean $(n=230)$. Values were corrected for abiotic hydrolysis when fluorochrome was released in killed controls. $H_{\mathrm{r}}\left(\% \mathrm{~d}^{-1}\right)$ were calculated by dividing hydrolysate production rates by $(0.01 \times$ analog concentration, $20 \mu \mathrm{M})$.

Bacterial dynamics. For bacterial abundances, water samples $(200 \mathrm{ml})$ were preserved with $2 \%$ (final conc.) borate-buffered formaldehyde and stored at $4^{\circ} \mathrm{C}$ until analyzed. In the laboratory, standard DAPI-stained slides were prepared on black $0.2 \mu \mathrm{m}$ polycarbonate membranes (Osmonics) for enumeration and biomass estimates of bacteria by epifluorescence microscopy (Porter \& Feig 1980, Taylor et al. 2003). Samples were stored $\leq 2$ mo before processing and no attempts were made to correct for storage-related losses of fluorescent cells (Turley \& Hughes 1994).

Bacterial net production (BNP) was estimated by 2 methods, using ${ }^{3} \mathrm{H}$-thymidine (Tdr) incorporation into DNA (Bell 1993) and ${ }^{3} \mathrm{H}$-leucine (Leu) incorporation into protein (Kirchman 1993). Details of both methods appear in Taylor et al. (2003). Cell production was estimated using $1 \times 10^{18}$ cells $\mathrm{mol}^{-1} \mathrm{Tdr}$, based on calibration studies with freshwater Hudson River communities reported by Findlay et al. (1991). Carbon production from the Tdr incorporation data was estimated by multiplying the cell production by estimates of average cell biomass determined microscopically. Carbon production from the Leu samples was estimated using a factor of $3.1 \mathrm{~kg} \mathrm{C} \mathrm{mol}^{-1}$ Leu (Kirchman 1993).

Monomer turnover. Heterotrophic turnover rates of acetate and glucose were determined by incubating separate whole water samples with sub-saturating radiotracer concentrations, either $15 \mathrm{nM}$ uniformly labeled ${ }^{14} \mathrm{C}$-glucose (final conc.) or $30 \mathrm{nM}$ ${ }^{14} \mathrm{C}$ - $[1,2]$ acetate in a dark flow-through water bath. Ambient glucose and acetate concentrations within these estuaries varied from 6 to 530 and 7 to $500 \mathrm{nM}$, respectively, according to kinetic-based estimates (Yu 1999). Turnover rate constants for these monomers were calculated as the sums of first-order slopes of incorporated and respired ${ }^{14} \mathrm{C}$ plotted against time. Substrate incorporated into biomass was measured as radioactivity retained on duplicate $0.2 \mu \mathrm{m}$ Nuclepore membranes over $5 \mathrm{~h}$ (Wright \& Hobbie 1966). Respired substrate was estimated by removing duplicate $20 \mathrm{ml}$ subsamples at each time point and fixing with $0.2 \mathrm{ml} 10 \mathrm{~N} \mathrm{KOH}$. In the laboratory, respired ${ }^{14} \mathrm{CO}_{2}$ was collected on a suspended filter soaked in $2 \mathrm{~N} \mathrm{KOH}$ after acidifying the alkalized sample with $0.2 \mathrm{ml}$ of $10 \mathrm{~N} \mathrm{H}_{2} \mathrm{SO}_{4}$ in a closed flask (Hobbie \& Crawford 1969). Filters and ${ }^{14} \mathrm{CO}_{2}$ traps were radioassayed in Optiflour scintillation liquid cocktail.

Phytoplankton biomass. Chlorophyll a (chl a) concentrations were determined fluorometrically from acetone extracts of triplicate 0.11 subsamples retained on GF/F filters. Values were corrected for contribution of pheopigments using the method of Parsons et al. (1984).

Organic carbon pools and nutrients. Sampling and processing protocols for particulate organic carbon (POC), DOC and inorganic nutrients are described in Taylor et al. (2003). Briefly, DOC was measured in triplicate using a Shimadzu TOC-5000 Total Organic Carbon Analyzer according to Sharp et al. (1995). POC was analyzed on triplicate subsamples of GF/F filters (47 mm) by combustion in a Carlo Erba EA1108 CHNSO analyzer (Martin 1993). Ammonium, nitrate, nitrite and phosphate were analyzed using automated colorimetric techniques described by Parsons et al. (1984). All nutrient and carbon concentrations were corrected with appropriate blanks.

Statistics. Least squares regressions, multiple regressions and Pearson product-moment correlations were performed with SigmaPlot 2001 and SigmaStat 2.0 (SPSS). Kruskal-Wallis Rank ANOVA and Kolmogorov-Smirnov Normality Tests were performed using SYSTAT (SPSS). For correlation tables, the group-wide type-I error rate (the probability that significant correlations arose by chance alone) was evaluated using the sequential Bonferroni test and a table-wide significance level, $\alpha$, of 0.05 (Rice 1989).

\section{RESULTS}

\section{Temporal variability}

Over the course of our observations, temperature of surface waters varied between 4.4 and $26.3^{\circ} \mathrm{C}$ or by nearly a factor of 6 (Fig. 2B). Activity of any given ectohydrolase varied as much as 450 -fold over this same period. Seasonal responses in activity, however, varied among ectohydrolases. For example, $\beta$-glucosidase activity varied from non-detectable to $47 \% \mathrm{~d}^{-1}$, more or less increasing from spring through summer and 


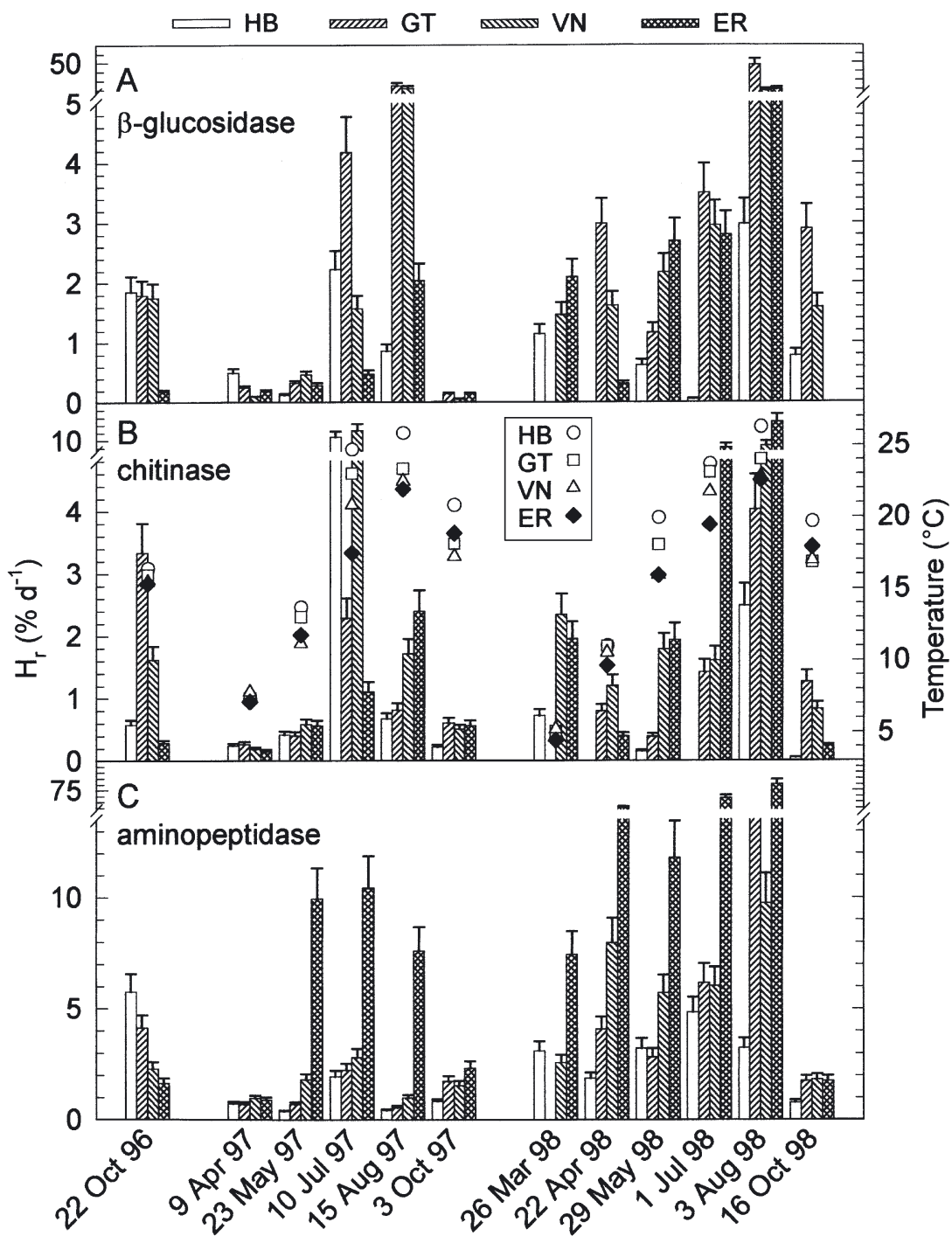

Fig. 2. Temporal variations in hydrolytic enctoenzyme activity and (B) water temperature $(0, \square, \Delta$, ) for the upper mixed layer of each sampling station. Missing bars indicate rates were below detection $\left(<0.1 \% \mathrm{~d}^{-1}\right)$. For station designations, see Fig. 1 . Error bars $=+\mathrm{SE}$ of rate estimate (regression slope of hydrolysate production vs time). $H_{\mathrm{r}}$ : potential turnover rate

\section{Spatial patterns}

In the Hudson River estuary, potential hydrolysis rate constants tended to be lowest at Stn HB for all but alkaline phosphatase (Fig. 3). In the cases of aminopeptidase and chitinase in the Hudson estuary, mean hydrolytic activities appeared to increase seaward with highest values at Stn VN. In the cases of $\beta$-glucosidase, lipase and alkaline phosphatase, activities tended to be higher and slightly more variable at Stn GT than at Stns HB or VN (Fig. 3). This site exhibited the widest excursions in salinity (0.70 to 16.74 on psu scale). Therefore, both substrate availability and plankton communities were likely to have been more heterogeneous here than elsewhere.

Relative to the Hudson stations, variance in ectohydrolase activity at Stn ER tended to be moderate to high (Fig. 3). Aminopeptidase activity at Stn ER equaled or surpassed that observed at the Hudson stations on all dates except October 1996. During the October 1996 cruise, unusually high activities observed for all ectohydrolases in the Hudson were not apparent at Stn ER (Fig. 2). The October 1996 cruise occurred 1 d after a freshwater discharge event of $957 \mathrm{~m}^{3} \mathrm{~s}^{-1}$ at Troy Dam due to heavy rains, resulting in discharges exceeding $400 \mathrm{~m}^{3} \mathrm{~s}^{-1}$ for another $7 \mathrm{~d}$. By comparison, freshwater discharge in September and October of 1997 or 1998 rarely exceeded $200 \mathrm{~m}^{3} \mathrm{~s}^{-1}$ (http://waterdata.usgs.gov/ nwis/dvstat).

Spatial patterns in enzyme activity did not seem to correspond directly to those of DOC, POC or chl a concentrations

(Fig. 4). For example, DOC concentra-

diminishing in October at all stations (Fig. 2A). Chitinase activity varied from 0.04 to $15 \% \mathrm{~d}^{-1}$, achieving maxima in July 1997 and July to August 1998 (Fig. 2B). However, its seasonality was less pronounced than that of $\beta$-glucosidase. In general, aminopeptidase activity was highest among the 5 ectohydrolases assayed, varying from 0.4 to $89 \% \mathrm{~d}^{-1}$, but exhibited the least seasonal variation (Fig. 2C). Lipase and alkaline phosphatase activities varied from non-detectable to $13 \% \mathrm{~d}^{-1}$ and from 0.6 to $15 \% \mathrm{~d}^{-1}$, respectively (not presented). However, too few nonzero lipase data exist to assess their seasonal variability and alkaline phosphatase was only assayed in 1998. tions were highest and most variable at Stn HB $(p<$ 0.005; Kruskal-Wallis ANOVA) and diminished toward the more marine stations (Fig. 4A). In contrast, mean activities for 4 of the 5 ectohydrolases were lowest at Stn HB and exhibited the least variance (Fig. 3). In fact, spatial patterns of aminopeptidase and chitinase activity appeared to relate inversely to patterns of DOC.

Mean POC concentrations varied between 60 and $80 \mu \mathrm{M} \mathrm{C}$ and did not differ significantly among stations (Fig. 4B). POC concentrations were most variable at Stn GT, which is located just seaward of the estuary's turbidity maximum and the largest sewage treatment plant on the Hudson. 


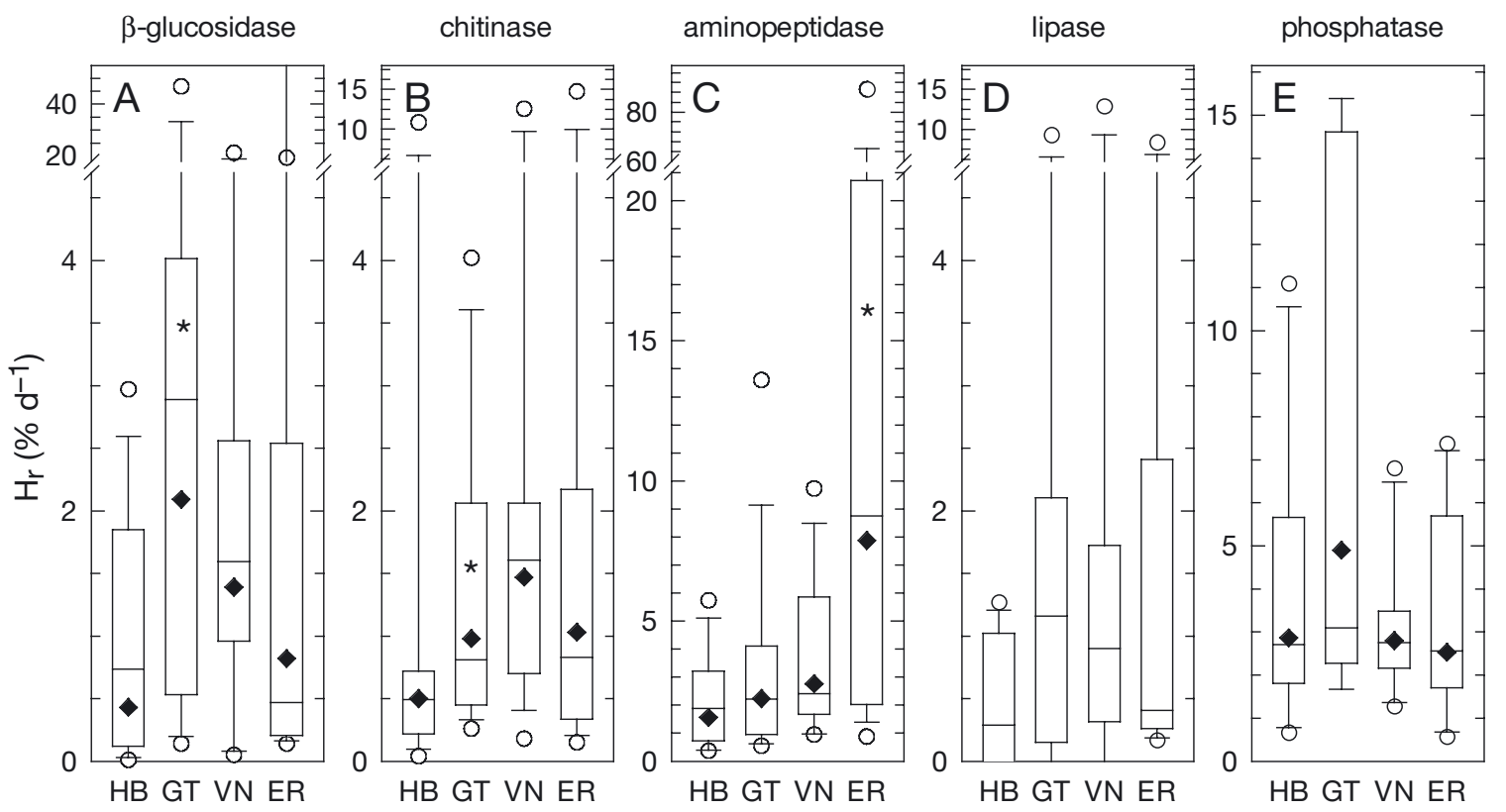

Fig. 3. Spatial trends for hydrolytic ectoenzyme activity surface waters. Boxes enclose $75 \%$ of all observations. Horizontal lines in boxes are medians; whiskers are the 90th percentiles. $(\bullet)$ Geometric means; (0) outliers. Number of samples is 6 for phosphatase and 12 for other hydrolases. Geometric means not presented for lipase due to numerous undetectable values. (*) Stations with median values significantly different $(\mathrm{p}<0.05)$ from Stn HB (Mann-Whitney Rank Sum test). $H_{\mathrm{r}}$ : potential turnover rate. See Fig. 1 for full station names

The relative contribution of autochthonous primary producers to POC pools can be surmised from chl a concentrations (Fig. 4C). The vigorously mixed and turbid stations, HB and GT, had significantly lower chl a concentrations than the other 2 stations, both averaging about $2 \mu \mathrm{g} \mathrm{l}^{-1}$. Plant biomass contributed between 2 and $59 \%$ to the total POC inventory at Stns HB and GT, with mean values of 19 and $15 \%$, respectively. Stns VN and
ER were deeper, more stratified, less turbid and supported higher chl a levels, averaging 4 and $17 \mu \mathrm{g} \mathrm{l}^{-1}$, respectively. At these stations, estimates of plant biomass accounted for relatively high proportions of the POC, generally contributing about $35 \%$ to the total POC pool at Stn VN and $113 \%$ at Stn ER (a reflection of the uncertainty in C:chl a ratios). Spatial patterns of chl a most closely resemble those of aminopeptidase (Figs. 3C \& 4C).

Table 1. Pearson product moment correlations (r) of ectohydrolase activities with other variables for Hudson River estuary stations. Unless otherwise noted, $\mathrm{n}=35$ samples. Uptake rate constants for glucose, acetate and leucine: $K_{\mathrm{gluc}}, K_{\mathrm{ace}}$ and $K_{\mathrm{leu}}$ bacterial net production (BNP) measured by ${ }^{3} \mathrm{H}-\mathrm{Tdr}$. Range of values presented in bottom set of parentheses. Statistical significance: $n s=p>0.05,{ }^{*} p<0.05,{ }^{* *} p<0.01,{ }^{* * *} p<0.005$

\begin{tabular}{|c|c|c|c|c|c|c|c|c|c|c|c|c|}
\hline & $\begin{array}{c}\text { Amino- } \\
\text { peptidase } \\
\left(\mathrm{d}^{-1}\right) \\
(0.4-14)\end{array}$ & $\begin{array}{c}\beta \text {-gluco- } \\
\text { sidase } \\
\left(\mathrm{d}^{-1}\right) \\
(0-47)\end{array}$ & $\begin{array}{l}\text { Chitinase } \\
\qquad\left(d^{-1}\right) \\
(0-12)\end{array}$ & $\begin{array}{c}\text { Lipase } \\
\left(\mathrm{d}^{-1}\right) \\
(\mathrm{n}=33) \\
(0-13)\end{array}$ & $\begin{array}{c}\text { Phosphatase } \\
\left(\mathrm{d}^{-1}\right) \\
(\mathrm{n}=17) \\
(0.7-15)\end{array}$ & $\begin{array}{c}\text { Temp. } \\
\left({ }^{\circ} \mathrm{C}\right)\end{array}$ & $\begin{array}{c}\text { Chl a } \\
\left(\mu g ~^{-1}\right) \\
(0.9-8.8)\end{array}$ & $\begin{array}{c}\text { Bacteria } \\
\left(\times 10^{8} \text { cells l}^{-1}\right) \\
(0.9-303)\end{array}$ & $\begin{array}{c}\begin{array}{c}K_{\text {gluc }} \\
\left(\mathrm{d}^{-1}\right)\end{array} \\
(0.0-9.3)\end{array}$ & $\begin{array}{c}K_{\mathrm{ace}} \\
\left(\mathrm{d}^{-1}\right) \\
(0.9-14.9)\end{array}$ & $\begin{array}{c}K_{\mathrm{leu}} \\
\left(\mathrm{d}^{-1}\right)\end{array}$ & $\begin{array}{c}\text { BNP } \\
\left(\mu g \mathrm{C}^{-1} \mathrm{~d}^{-1}\right) \\
(0.2-39)\end{array}$ \\
\hline Aminopeptidase & - & $0.56^{* * *}$ & ns & ns & $0.63^{* *}$ & ns & ns & $\mathrm{ns}$ & $0.85^{* * *}$ & $0.60^{* * *}$ & $0.79^{* * *}$ & $0.70^{* * *}$ \\
\hline$\beta$-glucosidase & & - & ns & $0.51^{* * *}$ & $0.65^{* * *}$ & $0.37^{* a}$ & ns & ns & $0.65^{* * *}$ & ns & $0.48^{* * *}$ & $0.60^{* * *}$ \\
\hline Chitinase & & & - & ns & ns & $0.35^{* a}$ & $0.68^{* * *}$ & ns & ns & ns & $0.37^{* a}$ & $\mathrm{~ns}$ \\
\hline Lipase & & & & - & $0.78^{* * *}$ & $0.37^{* a}$ & ns & ns & ns & ns & ns & ns \\
\hline Phosphatase & & & & & - & $0.58^{* \mathrm{a}}$ & ns & ns & $0.52^{* a}$ & ns & ns & $0.73^{* * *}$ \\
\hline Temperature & & & & & & - & ns & $\mathrm{ns}$ & ns & ns & $0.34^{* a}$ & $0.51^{* * *}$ \\
\hline Chl a & & & & & & & - & $\mathrm{ns}$ & ns & ns & ns & ns \\
\hline Bacteria & & & & & & & & - & ns & ns & ns & ns \\
\hline$K_{\text {gluc }}$ & & & & & & & & & - & $0.43^{* *}$ & $0.79^{* * *}$ & $0.75^{* * *}$ \\
\hline$K_{\text {ace }}$ & & & & & & & & & & - & $0.57^{* * *}$ & $0.57^{* * *}$ \\
\hline$K_{\text {leu }}$ & & & & & & & & & & & - & $0.82^{* * *}$ \\
\hline
\end{tabular}




\section{Ectohydrolase activity and plankton dynamics}

Dependence of ectohydrolase activity on phytoplankton biomass (chl a) or primary productivity might be expected either because algae and other plankters produce ectohydrolases or because bacterioplankton growth is supported by phytoplankton by-products. However, only chitinase activity in the Hudson appeared to covary with chl a (Tables $1 \& 2$ ). Chl a was also weakly correlated with bacterial abundance at Stn ER, but it was not correlated in the Hudson at all and did not covary with bacterial production (Tables 1 \& 2). Variance in primary production corresponded even less with ectohydrolase activity and bacterial variables than did chl a (Table 3).

Ectohydrolase activities in the Hudson correlated with bacterial production but not abundances (Table 1). At Stn ER, activities of aminopeptidase, $\beta$-glucosidase and chitinase were all highly correlated with bacterial abundances and production as well as with one another (Table 2). Temporal trends in aminopeptidase activity were particularly coherent with those of bacterial production at Stn ER, whether BNP was measured by Tdr or Leu methods (Fig. 5A). A common relationship between BNP and aminopeptidase was apparent among all stations, even those most geographically distant and hydrographically distinct (Stns HB and ER). These regressions explained between 61 and $80 \%$ of total variance $\left(\mathrm{r}^{2}\right)$ of these parameters in both estuaries, depending on the bacterial production method employed (Fig. 5B).

Bacterial production also correlated significantly with $\beta$-glucosidase activity in both estuaries (Tables 1 \& 2). In contrast, alkaline phosphatase was significantly correlated with BNP in the Hudson only, while

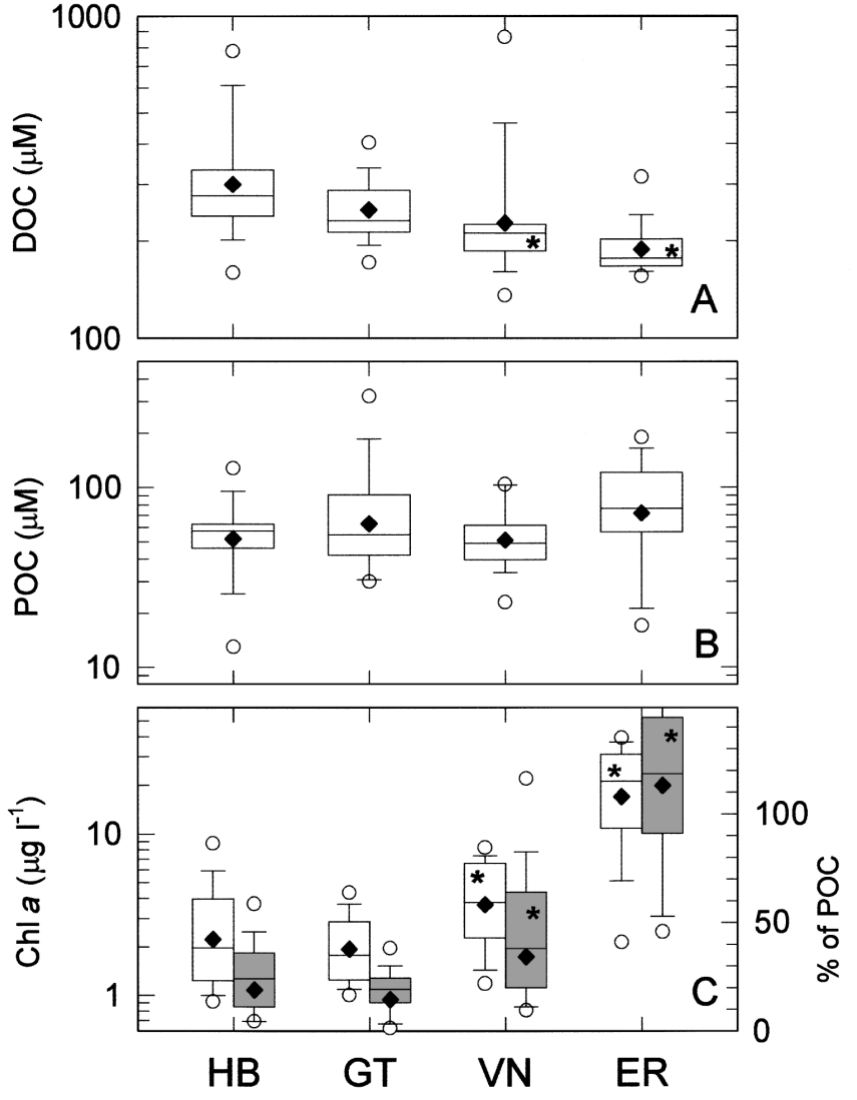

Fig. 4. Spatial trends for (A) dissolved organic carbon (DOC) concentrations, (B) particulate organic carbon (POC) concentrations and (C) chlorophyll a concentrations. Chl $a$, expressed as \% of total POC, presented in shaded boxes (assumes C:chl $a=58$; Tantichodok 1990). Box and whisker parameters same as in Fig. 3. Number of samples is 12 for each station. $(*)$ Stations with median concentrations significantly different $(p<0.05)$ from Stn HB (Mann-Whitney Rank Sum test). See Fig. 1 for full station names

Table 2. Pearson product moment correlations (r) of ectohydrolase activities with other plankton variables for Stn ER. Unless otherwise noted, $\mathrm{n}=12$ samples. Abbreviations and further information as in Table 1

\begin{tabular}{|c|c|c|c|c|c|c|c|c|c|c|c|c|}
\hline & $\begin{array}{c}\text { Amino- } \\
\text { peptidase } \\
\left(\mathrm{d}^{-1}\right) \\
(0.9-89)\end{array}$ & $\begin{array}{c}\beta \text {-gluco- } \\
\text { sidase } \\
\left(\mathrm{d}^{-1}\right) \\
(0-19)\end{array}$ & $\begin{array}{l}\text { Chitinase } \\
\qquad\left(\mathrm{d}^{-1}\right) \\
(0.2-15)\end{array}$ & $\begin{array}{c}\text { Lipase } \\
\left(\mathrm{d}^{-1}\right) \\
(\mathrm{n}=11) \\
(0-8)\end{array}$ & $\begin{array}{c}\text { Phosphatase } \\
\left(\mathrm{d}^{-1}\right) \\
(\mathrm{n}=6) \\
(0.6-7)\end{array}$ & $\begin{array}{c}\text { Temp. } \\
\left({ }^{\circ} \mathrm{C}\right) \\
(4.4-22.6)\end{array}$ & $\begin{array}{c}\text { Chl a } \\
\left(\mu \mathrm{g} \mathrm{l}^{-1}\right) \\
(2.1-39.1)\end{array}$ & $\begin{array}{c}\text { Bacteria } \\
\left(\times 10^{8} \text { cells l}^{-1}\right) \\
(5.9-287)\end{array}$ & $\begin{array}{l}\left.{ }^{1}\right) \begin{array}{l}K_{\text {gluc }} \\
\left(\mathrm{d}^{-1}\right)\end{array} \\
(0.1-13.4)\end{array}$ & $\begin{array}{c}\begin{array}{c}K_{\mathrm{ace}} \\
\left(\mathrm{d}^{-1}\right)\end{array} \\
(1.2-11.1)\end{array}$ & $\begin{array}{c}\begin{array}{c}K_{\text {leu }} \\
\left(\mathrm{d}^{-1}\right)\end{array} \\
(0.02-0.89)\end{array}$ & $\begin{array}{c}\mathrm{BNP} \\
\left(\mu \mathrm{g} \mathrm{l}^{-1} \mathrm{~d}^{-1}\right) \\
(4-76)\end{array}$ \\
\hline Aminopeptidase & - & $0.86^{* * *}$ & $0.95^{* * *}$ & ns & ns & ns & ns & $0.77^{* * *}$ & $0.96^{* * *}$ & $0.79^{* * *}$ & $0.90^{* * *}$ & $0.87^{* * *}$ \\
\hline$\beta$-glucosidase & & - & $0.93^{* * *}$ & ns & ns & $\mathrm{ns}$ & ns & $0.73^{* *}$ & $0.93^{* * *}$ & $0.84^{* * *}$ & $0.96^{* * *}$ & $0.96^{* * *}$ \\
\hline Chitinase & & & - & ns & $0.81^{* \mathrm{a}}$ & ns & ns & $0.78^{* * *}$ & $0.99^{* * *}$ & $0.87^{* * *}$ & $0.94^{* * *}$ & $0.94^{* * *}$ \\
\hline Lipase & & & & - & ns & ns & ns & ns & $\mathrm{ns}$ & $\mathrm{ns}$ & ns & $\mathrm{ns}$ \\
\hline Phosphatase & & & & & - & $\mathrm{ns}$ & $\mathrm{ns}$ & ns & ns & $\mathrm{ns}$ & $\mathrm{ns}$ & $\mathrm{ns}$ \\
\hline Temperature & & & & & & - & ns & ns & ns & $0.59 * \mathrm{a}$ & ns & $0.60^{* a}$ \\
\hline Chl a & & & & & & & - & $0.68^{* a}$ & ns & $\mathrm{ns}$ & $\mathrm{ns}$ & $\mathrm{ns}$ \\
\hline Bacteria & & & & & & & & - & ns & $\mathrm{ns}$ & $\mathrm{ns}$ & $\mathrm{ns}$ \\
\hline$K_{\text {gluc }}$ & & & & & & & & & - & $0.90^{* * *}$ & $0.93^{* * *}$ & $0.96^{* * *}$ \\
\hline$K_{\text {ace }}$ & & & & & & & & & & - & $0.84^{* * *}$ & $0.92^{* * *}$ \\
\hline$K_{\text {leu }}$ & & & & & & & & & & & - & $0.95^{* * *}$ \\
\hline
\end{tabular}


Table 3. Parameters varying independently of all measured ectohydrolase activities $\left(\% \mathrm{~d}^{-1}\right)$. Probabilities of significant correlation with any ectohydrolase were below $95 \%$ ( $p>0.05)$. TIN: total inorganic nitrogen

\begin{tabular}{|c|c|}
\hline Variable & Range \\
\hline River discharge $\left(\mathrm{m}^{3} \mathrm{~s}^{-1}\right)^{\mathrm{a}}$ & $129-1415$ \\
\hline Precipitation (cm) & $0-9.8$ \\
\hline Salinity (psu) & $0.13-26.22$ \\
\hline $\mathrm{DOC}(\mathrm{mM} \mathrm{C})$ & $136-4505$ \\
\hline $\mathrm{POC}(\mathrm{mM} \mathrm{C})$ & $13-321$ \\
\hline Primary production $\left(\mathrm{mg} \mathrm{C} \mathrm{m} \mathrm{m}^{-2} \mathrm{~d}^{-1}\right)^{\mathrm{b}}$ & $4-7200$ \\
\hline Microbial respiration $\left(\mu \mathrm{M} \mathrm{O}_{2} \mathrm{~h}^{-1}\right)^{\mathrm{c}}$ & $0.3-14.3$ \\
\hline $\mathrm{NH}_{4}^{+}(\mu \mathrm{M})^{\mathrm{d}}$ & $0.6-33.3$ \\
\hline $\mathrm{NO}_{3}^{-}(\mu \mathrm{M})$ & $0-45.1$ \\
\hline $\mathrm{NO}_{2}^{-}(\mu \mathrm{M})$ & $0.3-7.8$ \\
\hline $\operatorname{TIN}\left(\mathrm{NH}_{4}^{+}+\mathrm{NO}_{3}{ }^{-}+\mathrm{NO}_{2}^{-}\right)(\mu \mathrm{M})^{\mathrm{d}}$ & $1.2-70.3$ \\
\hline $\mathrm{PO}_{4}{ }^{3-}(\mu \mathrm{M})^{\mathrm{d}}$ & $0.3-4.6$ \\
\hline
\end{tabular}

${ }^{a}$ Applicable to Hudson River stations only. Complexity of circulation and lack of appropriate measurements (e.g. point source emissions) preclude any estimation of freshwater discharge rates through western Long Island Sound. One exception: phosphatase vs river discharge, $\mathrm{r}=-0.56, \mathrm{p}<0.01$. Range presented for freshwater flow at Troy Dam during sampling periods

${ }^{\mathrm{b}}$ Chitinase activities correlated marginally with primary production $(\mathrm{p}<0.05)$ at Hudson River stations only. Primary production methods and results presented in Taylor et al. (2003)

${ }^{\mathrm{c}}$ Aminopeptidase, $\beta$-glucosidase and chitinase activities correlated significantly $(\mathrm{p}<0.01)$ with this variable at Stn ER only. Other ectoenzymes did not correlate at any station. Respiration methods and results presented in Taylor et al. (2003)

${ }^{\mathrm{d}}$ In Hudson River, only significant correlations were between aminopeptidase and TIN (see Fig. 6) lipase with $\mathrm{NH}_{4}{ }^{+}(\mathrm{r}=0.47, \mathrm{p}<0.01, \mathrm{n}=33)$ and $\mathrm{PO}_{4}{ }^{3-}(\mathrm{r}=0.52, \mathrm{p}<$ $0.005, \mathrm{n}=33$ )

chitinase was only correlated with BNP in Long Island Sound. Lipase activity did not correlate with bacterial production in either estuary. While ectohydrolase activity was clearly more responsive to bacterial variables than to phytoplankton, bacterial cellspecific levels of ectohydrolase expression among samples were highly variable, i.e. fmol substrate bacterium ${ }^{-1} \mathrm{~d}^{-1}$.

\section{Ectohydrolase activity and monomer uptake}

Uptake of 2 specific monomers (acetate and glucose) were measured directly (production of ${ }^{14} \mathrm{C}$-particulates and ${ }^{14} \mathrm{CO}_{2}$ ). Turnover of a third monomer, leucine, was approximated using ${ }^{3} \mathrm{H}$-Leu BNP data, because $>90 \%$ of leucine uptake is usually incorporated into the ${ }^{3} \mathrm{H}$ protein that is measured in this assay (Kirchman et al. 1985). In the Hudson, turnover of ${ }^{14} \mathrm{C}$-glucose $\left(K_{\text {glu }}\right)$, ${ }^{14} \mathrm{C}$-acetate $\left(K_{\text {ace }}\right)$ and Leu $\left(K_{\text {leu }}\right)$ was strongly correlated with aminopeptidase activity (Table 1$)$. $\beta$-glucosidase
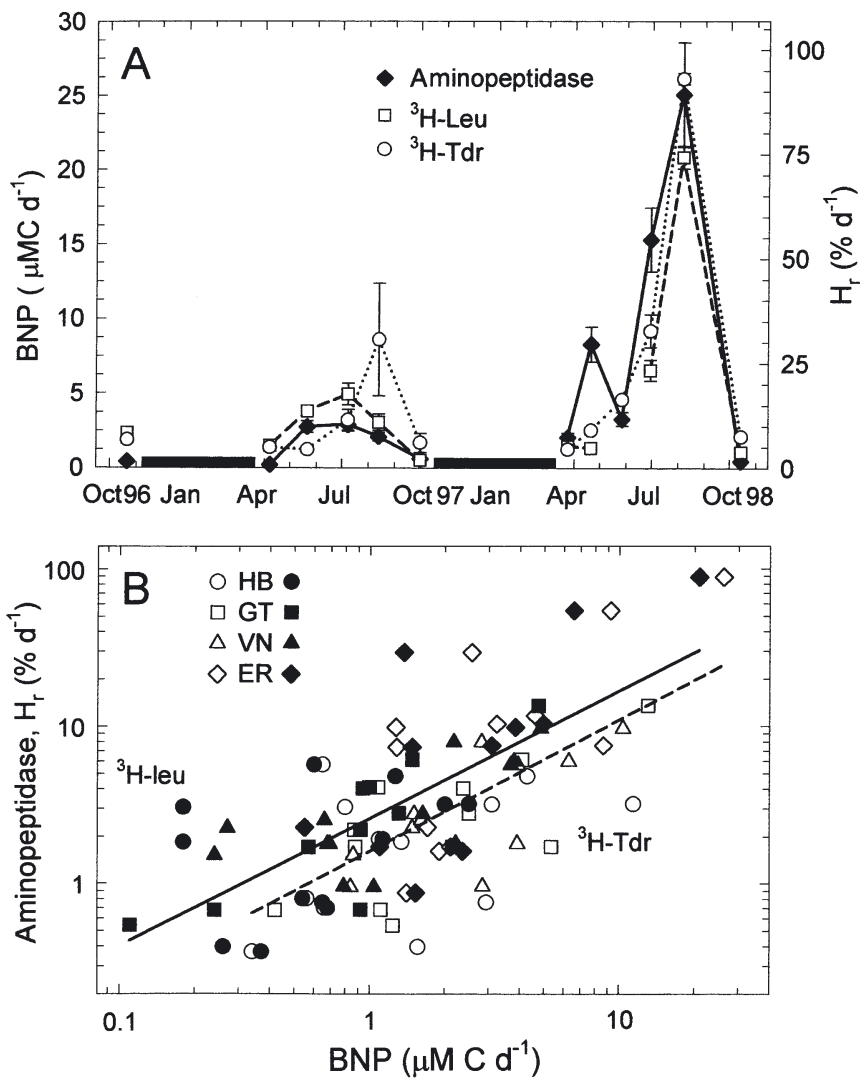

Fig. 5. Temporal variations in aminopeptidase activity (APA) and bacterial net production (BNP) in surface waters at (A) Stn ER and (B) their covariance among all stations. Thick black bar: no samples; dashed line: ${ }^{3} \mathrm{H}$-Leu trend; dotted line: ${ }^{3} \mathrm{H}$-Tdr trend; solid line: aminopeptidase trend. (A) BNP measured by ${ }^{3} \mathrm{H}-\mathrm{Tdr}$ and ${ }^{3} \mathrm{H}-\mathrm{leu}$ incorporation. Means $\pm \mathrm{SE}$ presented. (B) Dashed line: least squares regression of all ${ }^{3} \mathrm{H}-\mathrm{Tdr}$ data (open symbols); $\mathrm{APA}=-1.90+2.62 \mathrm{BNP}, \mathrm{r}^{2}=0.61, \mathrm{p}<0.001, \mathrm{n}=47$. Solid line: least squares regression of all ${ }^{3} \mathrm{H}$-leu data (closed symbols); $\mathrm{APA}=-1.68+4.26 \mathrm{BNP}, \mathrm{r}^{2}=0.80, \mathrm{p}<0.001, \mathrm{n}=46 . H_{\mathrm{r}}$ : potential turnover rate. See Fig. 1 for full station names

activity covaried with $K_{\text {glu }}$ and $K_{\text {leu }}$ chitinase with $K_{\text {leu }}$ and alkaline phosphatase with $K_{\text {glu }}$.

Relationships between turnover of all monomers and polymer hydrolysis were even stronger at Stn ER, particularly for aminopeptidase, $\beta$-glucosidase and chitinase (Table 2). We note that while some monomers are directly produced by the hydrolytic action of a particular ectoenzyme, others are not. For example, acetate is not produced through the actions of aminopeptidase, $\beta$-glucosidase or chitinase. Nonetheless, $K_{\text {ace }}$ was highly correlated with the activities of these ectohydrolases.

\section{Ectohydrolase activity and inorganic nutrients}

In other locations, expression of ectohydrolase activity has been related to inorganic nutrient limitation. 
With 2 notable exceptions, ectohydrolase activities did not correlate with inorganic nutrient concentrations in either of these estuaries (Table 3). A negative correlation between total inorganic nitrogen (TIN) concentrations and aminopeptidase activity was observed among all stations ( $\mathrm{r}=-0.54, \mathrm{p}<0.001$; Fig. 6). Comparable trends between phosphate concentrations and alkaline phosphatase activity were absent in both estuaries (Table 3). In the Hudson River estuary, however, phosphate concentrations and lipase activity were positively correlated $(\mathrm{r}=0.52, \mathrm{p}<0.005, \mathrm{n}=33)$, suggesting that lipase activity and dissolved inorganic phosphate liberation may be coupled through phospholipid release.

\section{DISCUSSION}

Observed ectohydrolase activities result from complex interactions among intrinsic (plankton community composition and physiology) and extrinsic factors (temperature, salinity, labile polymers, inorganic nutrients) in surface waters. Our correlation analyses, as well as algal enrichment and size fractionation experiments conducted at our stations (Way 2000), all strongly indicate that most ectohydrolase activity observed in these estuaries can be attributed to bacte-

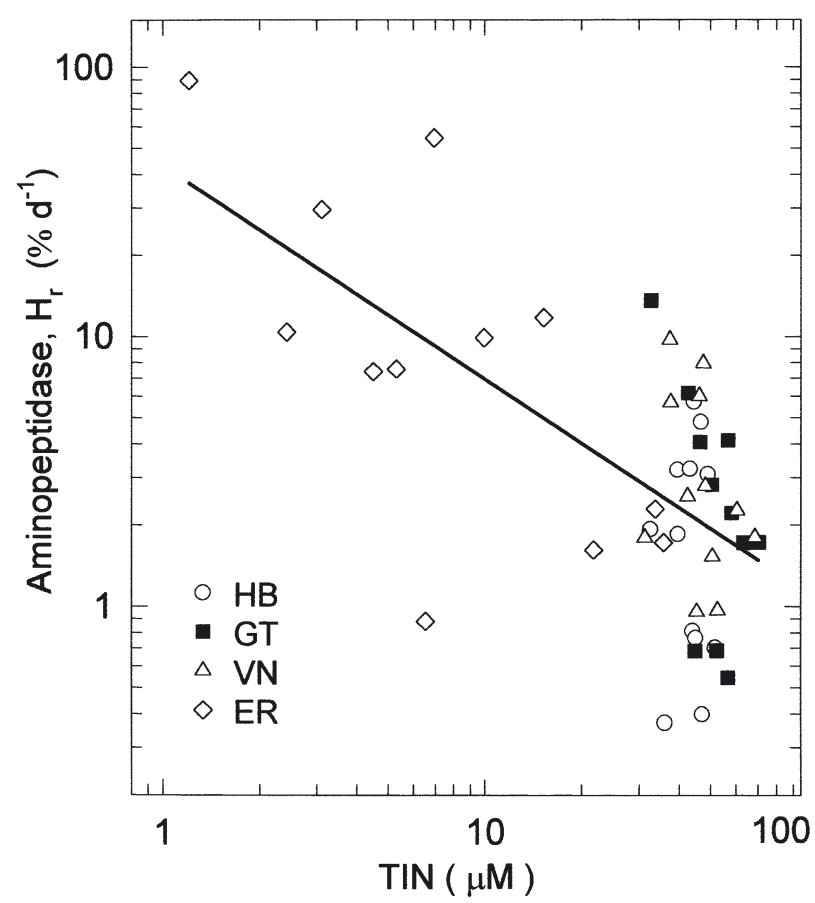

Fig. 6. Covariation of aminopeptidase activity and total inorganic nitrogen concentrations $\left(\right.$ TIN $=\mathrm{NH}_{4}{ }^{+}+\mathrm{NO}_{2}{ }^{-}+\mathrm{NO}_{3}{ }^{-}$) in surface waters of all stations. $\log$ APA $=1.63-0.79 \log$ TIN, $\mathrm{r}^{2}=0.40, \mathrm{n}=47, \mathrm{p}<0.001 . H_{\mathrm{r}}$ : potential turnover rate. See Fig. 1 for full station names ria. Beyond this, we have little information pertaining to intrinsic factors within the microplankton, such as species composition, nutritional requirements or physiology. Therefore, discussion will focus on extrinsic or environmental controls over community-level expression of ectohydrolase activity.

\section{Temperature}

Seasonal variability in bacterioplankton metabolism in temperate environments is often attributed largely to temperature dependence (Pomeroy \& Wiebe 2001). Mesophilic bacteria are purportedly more temperature-sensitive than phytoplankton, possessing $Q_{10}$ ratios that may exceed 3.0 compared to $\sim 2.0$ for microalgae (Shiah et al. 2000). In the Hudson, temperature could explain 35 to $58 \%$ of the variance in activities of $\beta$-glucosidase, chitinase, lipase and alkaline phosphatase, but with marginal significance (Table 1). In fact, sequential Bonferroni tests (Rice 1989) suggest that we cannot exclude the possibility that these weak correlations arose by chance alone. No correlation was found between temperature and aminopeptidase activity in the Hudson or between temperature and any ectohydrolase at Stn ER (Table 2).

Seasonal and interannual patterns in ectohydrolase activity and BNP suggest that responses to substrate availability surpass those to temperature. Aminopeptidase, chitinase and lipase activities differed significantly between years $(\mathrm{p}<0.05 ; t$-test), but water temperatures did not $(p>0.70)$, suggesting that communities were responding to variables other than temperature. Furthermore, the relatively high ectohydrolase activity observed in October 1996 and March to April 1998 in the Hudson occurred when water temperatures were moderate $\left(16^{\circ} \mathrm{C}\right)$ to low $\left(4.5^{\circ} \mathrm{C}\right)$ and corresponded to 2 brief accelerations in freshwater discharge (discussed below).

If observed hydrolysis rates were strongly controlled by temperature, then variance in ectohydrolase activity might best be explained by multiple regression analyses that include temperature. However, little or no improvement in describing variance in any ectohydrolase activity was evident by including temperature in multiple linear regressions of enzyme activity against DOC, POC, TIN, $\mathrm{PO}_{4}{ }^{3-}$, bacterial abundances, $\mathrm{BNP}$, chl $a$ or net primary production (NPP). Of the few significant regressions, more than $90 \%$ of the explained variance was attributable to nutrient or biotic properties and the remainder to temperature (not presented). Our results suggest that the physiological temperature optima of plankton in these estuaries vary through the year. Temperature appears to only exert modest control over ectohydrolase activity in 
these complex communities, and other factors such as nutrient regime appear to have greater influence.

\section{Labile polymer supply}

Previous studies have ascribed variance in relative activities of ectohydrolases along nutrient and salinity gradients to changes in available organic substrates (Karner et al. 1992, Hoppe et al. 1998, Cunha et al. 2000). In the present study, correlations between activity of any ectohydrolase and salinity, DOC or POC were non-existent (Table 3). Similar to many estuaries, DOC concentrations were conservative relative to mixing between fresh and saline end-members in the Hudson, decreasing systematically down-estuary during this study (Taylor et al. 2003). However, mean POC concentrations were nearly equal at all 3 Hudson stations (Fig. 4B). The higher variance observed in POC concentrations at Stn GT probably reflects its proximity to the turbidity maximum within the estuary's salt wedge and may also indicate the fluctuating influence of a large sewage outfall. Non-conservative enrichments in DOC, inorganic nutrients and biotic properties along the Hudson's salinity mixing curve have been reported previously and are indicative of lateral input of labile materials (Sañudo-Wilhelmy \& Taylor 1999, Taylor et al. 2003). However, variations in OC input caused by surface runoff, point sources and in situ processes as water flows through this complex estuary remain poorly described.

In estuaries, loadings, lability and provenance of OC are controlled by the interplay of freshwater discharge, point source input, sediment resuspension and estuarine mixing. Several lines of evidence indicate that organic matter lability varied independently of concentrations of DOC or POC and of estuarine mixing in our systems. In the Hudson, spatial trends in ectohydrolases and bacterial production opposed those of DOC (Figs. 3 \& 4 herein; Taylor et al. 2003), implying that the labile portion of a diminishing DOC pool increased down-estuary. While POC concentrations did not significantly differ among stations, POC quality did. Proportions of POC inventories accounted for by algae were minor at Stns HB and GT (<20\%) and were significantly greater at Stn VN (35\%) (Fig. 4C). At Stn ER, POC concentrations and quality (chl a contribution) were highest and the mean and variance of DOC concentrations were lowest among all stations (Fig. 4). Nonetheless, Stn ER, like VN, consistently supported significantly higher BNP rates than Stns HB and GT (Fig. 5). These observations suggest that labile substrates were supplied more rapidly at the stations exhibiting lower DOC concentrations and higher POC quality. Possible pathways supplying these labile substrates include phytoplankton exudation, hydrolysis of autochthonous biogenic debris (moribund cells, feces, molts, etc.), heterotrophic excretion and external loadings.

Although ectohydrolase activity was not directly correlated with freshwater discharge, DOC or POC, interannual comparisons suggest that more labile organic matter was provided from the watershed and utilized in the estuary during the wetter year (1998). During the 1998 sampling period, Hudson freshwater discharge was significantly higher $\left(\right.$ mean $=275 \mathrm{~m}^{3}$ $\mathrm{s}^{-1}$ ) than during the comparable interval in 1997 $\left(\right.$ mean $\left.=150 \mathrm{~m}^{3} \mathrm{~s}^{-1}\right)$ (Taylor et al. 2003). Coincidentally, mean concentrations of DOC (270 vs $196 \mu \mathrm{M} \mathrm{C}$; $\mathrm{p}<0.0001, t$-test) and POC (88 vs $54 \mu \mathrm{M} \mathrm{C}$; p < 0.05) were significantly higher in 1998 than in 1997. Likewise, activities of aminopeptidase, chitinase and lipase, bacterial abundances and BNP in 1998 were significantly greater than in 1997 at our Hudson stations (this study, Taylor et al. 2003). These findings suggest that supply of labile polymers is influenced by total freshwater discharge but its influence on the provenance and composition of this material is unknown.

\section{Ectoenzyme activity profiles}

Composition of labile substrates might be crudely assessed using ectohydrolase activities as proxies, if community expression of ectohydrolase activity is, in fact, proportional to bioavailable polymers (Chróst \& Rai 1993, Sinsabaugh et al. 1997). Relative activities of ectohydrolases have been used to infer which classes of macromolecules are important to the nutrition of bacterioplankton communities in a variety of environments (Christian \& Karl 1995, Sala et al. 2001). To accomplish this in our study, mean percentages of total measured hydrolysis were calculated for each station, using the 6 cruises when all 5 enzymes were assayed simultaneously (Fig. 7). At Stn HB, aminopeptidase and alkaline phosphatase appeared to be equally important, each contributing over $40 \%$ of total potential hydrolase activity. $\beta$-glucosidase, chitinase and lipase were of minor importance, comprising 6, 4 and $2 \%$ of the remaining activity. Ectohydrolase results suggest that plankton at Stn HB was relatively inactive and primarily acclimated to hydrolysis of proteins and phosphate-bearing organics (Figs. $3 \& 7$ ).

Plankton communities at Stn GT expressed moderate to high ectohydrolase activity levels (Fig. 3) and $\beta$-glucosidase contributed more to total hydrolase activity than at any other station (Fig. 7). These communities appeared to be equally acclimated to hydrolyzing proteins, polysaccharides and phosphate- 


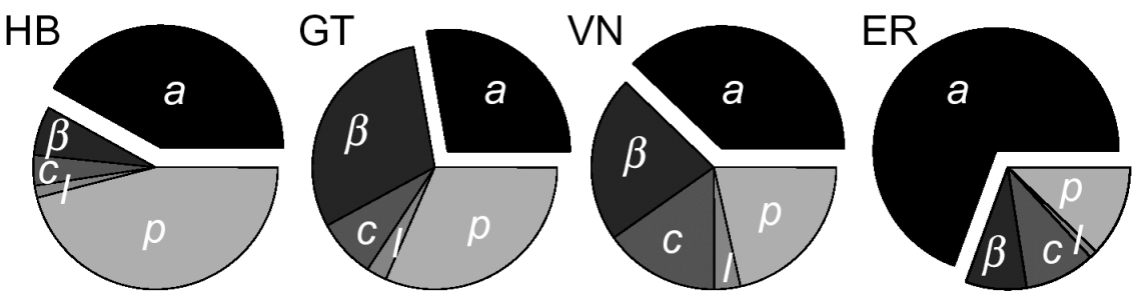

Fig. 7. Relative activities of $\beta$-glucosidase ( $\beta$ ), chitinase (c), aminopeptidase (a), lipase (l) and alkaline phosphatase (p) among surface waters at the 4 stations (HB, GT, VN and ER). Data include only last 6 cruises in which all ectohydrolases were measured simultaneously and presented as mean percentages of total hydrolase activity $\left(\% \mathrm{~d}^{-1}\right)$. See Fig. 1 for full station names

bearing organics because aminopeptidase, alkaline phosphatase and $\beta$-glucosidase all contributed about $30 \%$ to total ectohydrolase activity. In contrast, lipase only contributed $3 \%$ to the total.

At Stn VN, total activity was more evenly distributed among 4 of the 5 ectohydrolases than elsewhere, with aminopeptidase, $\beta$-glucosidase, chitinase and alkaline phosphatase contributing 38, 22, 15 and $21 \%$ of total activity, respectively. Lipase contributed the remaining $4 \%$ to total activity. Communities at this station appear to have been acclimated to a more balanced supply of protein, polysaccharides, chitin and phosphate-bearing organics than at the other stations.

Communities at Stn ER appeared to be most strongly adapted to protein decomposition, with the majority of their ectohydrolase allocation expressed as aminopeptidase ( $70 \%$ of total activity) and the remainder nearly evenly divided among $\beta$-glucosidase $(8 \%)$, chitinase (9\%) and alkaline phosphatase (12\%) (Fig. 7). Again lipase was of minor importance, representing only $1 \%$ of total activity.

\section{Ectohydrolases and nutrient acquisition}

Current theory holds that uptake of organic substrates and subsequent bacterial production are generally limited by rates of particle and polymer hydrolysis in aquatic systems because concentrations and residence times of most labile monomers and oligomers are generally low (Fuhrman \& Ferguson 1986, Hoppe et al. 1988, 1993, Azam \& Smith 1991). Hydrolytic activity at the community level has been related to decomposition, nutrient and energy limitation and secondary production in terms of an optimal resource allocation model (Sinsabaugh et al. 1997). The foundation of this model is that osmotrophic communities will optimize their energy expenditures by expressing high levels of a particular ectohydrolase only if polymeric substrates are abundant and monomeric hydrolysis products required for growth are scarce. Results for each of the ectohydrolases are evaluated below in the context of this model.

\section{Aminopeptidase}

The consistently high hydrolysis rates observed throughout this study suggest that aminopeptidase activity and proteinaceous materials are of paramount importance to bacterial communities in the Hudson River and western Long Island Sound estuaries. Strong covariance between aminopeptidase and BNP has been reported previously for several freshwater systems, including the tidal freshwater Hudson River, eutrophic lakes and a brackish fjord (Chróst et al. 1989, Sinsabaugh et al. 1997, Hoppe et al. 1998). In the present study, highest rates of BNP were generally observed in samples with the highest aminopeptidase activity. From this we conclude that acquisition of dissolved free amino acids (DFAA) appears to be a key determinant of heterotrophic bacterial production in these estuaries.

In the Adriatic Sea, covariations in aminopeptidase activity, concentrations of DFAA and BNP have been observed (Müller-Niklas et al. 1994). Close correlations between aminopeptidase activity and leucine assimilation have been reported for the Kiel Fjord and along a trophic gradient in the Swale River (Hoppe et al. 1988, Ainsworth \& Goulder 2000). We too observed that aminopeptidase activity was significantly correlated with turnover of leucine as well as with glucose and acetate turnover at all stations. However, demonstrations of close coupling between hydrolysis and uptake are hampered by the inability to accurately calculate absolute rates because ambient substrate concentrations are unknown. While our results do not permit direct quantitative mass balances of monomer production and consumption, they do illustrate that these processes are interdependent. These strong correlations illustrate that the processes of polymer hydrolysis and assimilation of a variety of monomers respond to shared environmental and biotic controls.

Aminopeptidase is important for both carbon and nitrogen acquisition (Chróst 1991, Kroer et al. 1994, Christian \& Karl 1995, Sinsabaugh et al. 1997). In natural waters ranging from riverine to oceanic systems, proteins and peptides can support 10 to $45 \%$ of C 
demand and 42 to $112 \%$ of $\mathrm{N}$ demand of bacterioplankton, while DFAA pools alone fall far short of meeting these demands (Kroer et al. 1994). In the present study, TIN concentrations correlated negatively with aminopeptidase activity (Fig. 6), suggesting that aminopeptidase production may be regulated in part by nitrogen limitation. Similar observations made by Chróst (1991) and Sinsabaugh et al. (1997) for marine and freshwater systems suggest that this relationship is not unique to our study area. These trends suggest an adaptive allocation of resources to conserve energy, while providing essential elements for bacterial growth by liberating DFAA from proteins.

\section{Chitinase}

Previous results from the tidal freshwater Hudson River suggest that chitinase is important in the production of low molecular weight DOC (Sinsabaugh et al. 1997), specifically $\mathrm{N}$-acetylglucosamine, a source of $\mathrm{C}$ and N. Sources of chitin in estuaries are likely to be cell walls of fungi and some chlorophytes, exoskeletons of insects and crustaceans, fecal pellet peritrophic membranes, and extracellular material produced by some diatoms and prymnesiophytes (Cottrell et al. 1999). While expression of chitinase activity was not high at any of our stations, its seasonal and spatial patterns were very similar to those of aminopeptidase and monomer turnover, suggesting that they are all controlled by similar environmental factors. Chitinase activity increased with salinity in the Hudson and covaried with chl $a$, primary production and BNP. This is consistent with Hoppe et al.'s (1998) prediction that chitinase activity would covary with phytoplankton and zooplankton production.

\section{$\beta$-glucosidase}

Activities of $\beta$-glucosidase were nearly always detectable because it is a low-specificity enzyme, hydrolyzing many forms of polysaccharides produced by microalgae and vascular plants, and releasing energy-bearing sugars (Chróst 1991). Potential activities in the upper estuary (Stn HB) were comparable to $V_{\max }$ found upriver in the Hudson and in other rivers by Sinsabaugh et al. (1997), and increased at Stn GT. Much of the cellulose-rich terrigenous matter entering the Hudson River appears to be consumed before entering the estuary at Stn HB (Howarth et al. 1996, Findlay et al. 1998, Taylor et al. 2003). Therefore, new inputs of polysaccharides, presumably from point sources, must occur between Stns HB and GT because Stn GT exhibits higher $\beta$-glucosidase activity than any other station.
Covariance between $\beta$-glucosidase activity and uptake of ${ }^{14} \mathrm{C}$-glucose has been demonstrated for the eutrophied Scheldt estuary, a eutrophied lake and a Baltic Sea fjord (Somville 1984, Chróst et al. 1989, Hoppe et al. 1998). Strong, positive correlations between $\beta$-glucosidase activity and $K_{\text {glu }}$ were also observed in the present study. In the Hudson, this association was strongest at Stn GT and weakest at Stn HB, supporting the proposal that polysaccharides were more important in the diet of bacterial communities mid-estuary (Fig. 7). At Stn ER, $\beta$-glucosidase was highly correlated with turnover of all 3 monomers, suggesting that its activity reflects general levels of community metabolism in these waters.

\section{Lipase}

Lipase activity has rarely been reported for microplanktonic communities in natural waters. Using MUF-ace in the tidal freshwater Hudson and 2 other rivers, apparent lipase activities contributed on average 34 to $43 \%$ to total enzyme activity and were generally greater than any other ectohydrolase assayed (Sinsabaugh et al. 1997, Findlay et al. 1998). In marine studies, lipase activity appears to be somewhat subordinate to other ectohydrolases assayed, usually representing $<20 \%$ of total hydrolase activity (Müller-Niklas et al. 1994, Martinez et al. 1996). In the present study, however, average lipase activity was lowest among the 5 ectohydrolases at all stations, contributing only 1 to $3.5 \%$ to total hydrolase activity, with rate constants varying from $<0.1$ to $13 \% \mathrm{~d}^{-1}$.

The subordinate activity of lipase and the independence of its variance with that of monomer turnover are unexpected (Fig. 7, Tables $1 \& 2$ ). Fatty acids are abundant in fresh biogenic debris and are known to be a common source of energy and carbon for heterotrophic bacteria. All 41 marine bacterial isolates screened by Martinez et al. (1996) expressed lipase activity. We do not know whether disparities in the relative importance of lipase among studies reflect real community differences or the choice of tracer used to measure lipase activity. In our hands, MUF-ace yielded high hydrolysis rates in killed control and experimental samples alike and its use was abandoned early in our study. Sinsabaugh et al. (1997) and Findlay et al. (1998) also report MUF-ace instability and cast doubt on any results derived from this tracer. The moderate rates reported by Martinez et al. (1996) were obtained with MUF-oleate, an unsaturated fatty acid analog (18:1), while we used the saturated MUF-palmitate (16:0). Even though both fatty acids are sparingly soluble in water, the lower melting point (mp) of oleate 
$\left(13.4^{\circ} \mathrm{C}\right)$ may confer more bioavailability at environmental temperatures than that of palmitate $(\mathrm{mp}=$ $\left.63.1^{\circ} \mathrm{C}\right)$.

\section{Alkaline phosphatase}

The inverse correlations between phosphorus concentrations and alkaline phosphatase activity observed in lacustrine, estuarine and coastal environments has led to the suggestion that planktonic expression of alkaline phosphatase is a response to phosphorus limitation (Suida \& Chróst 1987, Ammerman 1991). Chróst \& Rai (1993) observed higher levels of alkaline phosphatase in nutrient-impoverished freshwater mesocosms, while $\beta$-glucosidase became more important in nutrient-rich systems. Apparently, when inorganic nutrient limitation is relaxed, bacteria express higher capacities for carbon and energy-acquiring ectohydrolases, such as $\beta$-glucosidase. We found that alkaline phosphatase activity was often highest in the low salinity part of the Hudson (Stn $\mathrm{HB}$ ), where $\mathrm{PO}_{4}{ }^{3-}$ concentrations were lowest. While alkaline phosphatase activity was often a large percentage of total enzyme activity, its importance diminished down-estuary and it did not covary systematically with $\mathrm{PO}_{4}{ }^{3-}$ concentrations. P-limitation may not have been important at the more marine stations, since $\mathrm{PO}_{4}{ }^{3-}$ rarely fell below $2 \mu \mathrm{M}$ at Stn GT or VN.

\section{CONCLUSIONS}

Strong seasonal signals in ectohydrolase activity in the Hudson River estuary and western Long Island Sound seem to reflect community-level responses to labile substrate availability more than to temperature control. Labile substrate availability, not apparent from bulk measurements of OC concentrations, may be indirectly reflected by levels of ectohydrolase activity. Hydrolase activity profiles clearly indicate that plankton communities were adapted to utilize unique assortments of macromolecules at each station, presumably driven by fluctuating quality of polymeric pools. While all ectohydrolases, except lipase, were important in degrading polymers to varying degrees, aminopeptidase consistently accounted for large portions of total hydrolytic activity, irrespective of nutrient regime. Furthermore, aminopeptidase covaried with bacterial production among all stations, which represent a wide variety of trophic conditions. This generality demonstrates the importance of protein decomposition to bacterioplankton communities.

Activities of several ectohydrolases appear to respond to inorganic nutrient regimes as well. For example, $\mathrm{N}$ - and $\mathrm{P}$-acquiring hydrolases were most active in samples containing lowest concentrations of inorganic $\mathrm{N}$ and $\mathrm{P}$. On average, hydrolysis rates measured with $20 \mu \mathrm{M}$ additions of fluorogenic substrate correspond to 2600,530 and $2800 \%$ of C-, N- and Pbased bacterial production, respectively. This estimate assumes that all hydrolases, except alkaline phosphatase, are C-acquiring, aminopeptidase and chitinase are $\mathrm{N}$-acquiring and that bacteria possess a $\mathrm{C}: \mathrm{N}: \mathrm{P}$ of 45:9:1 (Fagerbakke et al. 1996). Robust correlations between activities of several ectohydrolases and turnover of leucine, glucose and acetate were also found. These results illustrate by totally independent measurements that monomer uptake by bacterioplankton is closely coupled to their hydrolytic production from polymers over a range of nutrient regimes.

Acknowledgements. The authors are indebted to the captains and crew of the RV 'Onrust'. For their cruise participation and technical assistance, we are also grateful to J. Gulnick, T.-Y. Ho, L. Klahre, M. Lee, K. Mantione, A. Modanesi, L. Oremland, J. Simpson and T. Wagoner. We thank D. Hirschberg for POC and DOC analyses and R. E. Wilson for fruitful discussions on estuarine circulation. We are indebted to Chesapeake Biological Laboratory's Nutrient Analytical Services (University of Maryland) for inorganic nutrients analyses. We thank the 4 anonymous reviewers whose thoughtful comments contributed greatly to this manuscript. This research was supported by Hudson River Foundation Grant No. 012/96A. Marine Sciences Research Center contribution no. 1274 .

\section{LITERATURE CITED}

Ainsworth AM, Goulder R (2000) The effects of sewageworks effluent on riverine extracellular aminopeptidase activity and microbial leucine assimilation. Water Res 34: $2551-2557$

Ammerman JW (1991) Role of ecto-phosphohydrolases in phosphorus regeneration in estuarine and coastal ecosystems. In: Chróst RJ (ed) Microbial enzymes in aquatic environments. Springer-Verlag, Berlin, p 25-59

Amon RMW, Benner R (1994) Rapid cycling of high molecular weight dissolved organic matter in the ocean. Nature 369 : $549-552$

Amon RMW, Benner R (1996) Bacterial utilization of different size classes of dissolved organic matter. Limnol Oceanogr 41:41-51

Anderson TH, Taylor GT (2001) Nutrient pulses, plankton blooms, and seasonal hypoxia in western Long Island Sound. Estuaries 24:228-243

Azam F, Smith DC (1991) Bacterial influence on the variability in the ocean's biogeochemical state: a mechanistic view. In: Demers S (ed) Particle analysis in oceanography. NATO ASI Series, Vol G27. Springer-Verlag, Berlin, p 213-236

Bell RT (1993) Estimating production of heterotrophic bacterioplankton via incorporation of tritiated thymidine. In: Kemp PF, Sherr BF, Sherr EB, Cole JJ (eds) Handbook of methods in aquatic microbial ecology. Lewis Publishers, Boca Raton, FL, p 495-504 
Benner R, Opsahl S, Chin-Leo G, Richey JE, Forsberg B (1995) Bacterial carbon metabolism in the Amazon River system. Limnol Oceanogr 40:1262-1270

Christian JR, Karl DM (1995) Bacterial ectoenzymes in marine waters: activity ratios and temperature responses in 3 oceanographic provinces. Limnol Oceanogr 40:1042-1049

Chróst RJ (1991) Microbial ectoenzymes in aquatic environments. In: Chróst RJ (ed) Microbial enzymes in aquatic environments. Springer-Verlag, New York, p 29-54

Chróst RJ, Rai H (1993) Ectoenzyme activity and bacterial secondary production in nutrient-impoverished and nutrientenriched freshwater mesocosms. Microb Ecol 25:131-150

Chróst RJ, Velimirov B (1991) Measurement of enzyme kinetics in water samples: effect of freezing and soluble stabilizer. Mar Ecol Prog Ser 70:93-100

Chróst RJ, Munster U, Rai H, Albrecht D, Witzel P, Overbeck J (1989) Photosynthetic production and exoenzymatic degradation of organic matter in the euphotic zone of a eutrophic lake. J Plankton Res 11:223-242

Clark JF, Simpson HJ, Bopp RF, Deck B (1992) Geochemistry and loading history of phosphate and silicate in the Hudson Estuary. Estuar Coast Shelf Sci 34:213-233

Cottrell MT, Moore JA, Kirchman DL (1999) Chitinases from uncultured marine microorganisms. Appl Environ Microbiol 65:2553-2557

Cunha MA, Almeida MA, Alcântra F (2000) Patterns of ectoenzymatic and heterotrophic bacterial activities along a salinity gradient in a shallow tidal estuary. Mar Ecol Prog Ser 204:1-12

Dai M, Martin JM, Cauwet G (1995) The significant role of colloids in the transport and transformation of organic carbon and associated trace metals $(\mathrm{Cd}, \mathrm{Cu}$, and $\mathrm{Ni})$ in the Rhône delta (France). Mar Chem 51:159-175

Fagerbakke KM, Heldal M, Norland S (1996) Content of carbon, nitrogen, oxygen, sulfur and phosphorus in native aquatic bacteria. Aquat Microb Ecol 10:15-27

Findlay S, Pace ML, Lints D, Cole JJ, Caraco NF, Peierls B (1991) Weak coupling of bacterial and algal production in a heterotrophic ecosystem: the Hudson River estuary. Limnol Oceanogr 36:268-278

Findlay S, Sinsabaugh RL, Fischer DT, Franchini P (1998) Sources of dissolved organic carbon supporting planktonic bacterial production in the tidal freshwater Hudson River. Ecosystems 1:227-239

Fuhrman JA, Ferguson RL (1986) Nanomolar concentrations and rapid turnover of dissolved free amino acids in seawater: agreement between chemical and microbiological measurements. Mar Ecol Prog Ser 33:237-242

Guo L, Coleman CH, Santschi PH (1994) The distribution of colloidal and dissolved organic carbon in the Gulf of Mexico. Mar Chem 45:105-119

Hobbie JE, Crawford CC (1969) Respiration corrections for bacterial uptake of dissolved compounds in natural waters. Limnol Oceanogr 14:528-532

Hollibaugh JT, Azam F (1983) Microbial degradation of dissolved proteins in seawater. Limnol Oceanogr 28: $1104-1116$

Hoppe HG (1983) Significance of exoenzymatic activities in the ecology of brackish water: measurements by means of methylumbelliferyl-substrates. Mar Ecol Prog Ser 11: 299-308

Hoppe HG (1993) Use of fluorogenic model substrates for extracellular enzyme activity (EEA) measurement of bacteria. In: Kemp PF, Sherr BF, Sherr EB, Cole JJ (eds) Handbook of methods in aquatic microbial ecology. Lewis Publishers, Boca Raton, FL p 423-430

Hoppe HG, Kim SJ, Gocke K (1988) Microbial decomposition in aquatic environments: combined process of extracellular enzyme activity and substrate uptake. Appl Environ Microbiol 54:784-790

Hoppe HG, Ducklow H, Karrasch B (1993) Evidence for dependency of bacterial growth on enzymatic hydrolysis of particulate organic matter in the mesopelagic ocean. Mar Ecol Prog Ser 93:277-283

Hoppe HG, Geisenhagen HC, Gocke K (1998) Changing patterns of bacterial substrate decomposition in a eutrophication gradient. Aquat Microb Ecol 15:1-13

Howarth RW, Schneider R, Swaney D (1996) Metabolism and organic carbon fluxes in the tidal freshwater Hudson River. Estuaries 19:848-865

Howarth RW, Swaney DP, Butler TJ, Marino R (2000) Climatic control on eutrophication of the Hudson River estuary. Ecosystems 3:210-215

Karner M, Herndl G (1992) Extracellular enzymatic activity and secondary production in free-living and marinesnow-associated bacteria. Mar Biol 113:341-347

Karner M, Fuks D, Herndl G (1992) Bacterial activity along a trophic gradient. Microb Ecol 24:243-257

Kempe S (1984) Sinks of the anthropogenically enhanced carbon cycle in surface fresh waters. J Geophys Res 89: 4657-4676

Kirchman DL (1993) Leucine incorporation as a measure of biomass production by heterotrophic bacteria. In: Kemp PF, Sherr BF, Sherr EB, Cole JJ (eds) Handbook of methods in aquatic microbial ecology. Lewis Publishers, Boca Raton, FL, p 509-512

Kirchman DL, K'Nees E, Hodson R (1985) Leucine incorporation and its potential as a measure of protein synthesis by bacteria in natural aquatic systems. Appl Environ Microbiol 49:599-607

Kroer N, Jørgensen NOG, Coffin RB (1994) Utilization of dissolved nitrogen by heterotrophic bacterioplankton: a comparison of three ecosystems. Appl Environ Microbiol 60: $4116-4123$

Martin JH (1993) Determination of particulate organic carbon (POC) and nitrogen (PON) in seawater. In: Kadar S, Leinen M, Murray JW (eds) United States Joint Global Ocean Flux Study: equatorial Pacific study - sampling and analytical protocols. US JGOFS, Woods Hole, MA, p 37-40

Martinez J, Smith DC, Steward GF, Azam F (1996) Variability in ectohydrolytic enzyme activities of pelagic marine bacteria and its significance for substrate processing in the sea. Aquat Microb Ecol 10:223-230

Müller-Niklas G, Schuster S, Kaltenböck E, Herndl GJ (1994) Organic content and bacterial metabolism in amorphous aggregates of the northern Adriatic Sea. Limnol Oceanogr 39:58-68

Parsons TR, Maita Y, Lalli CM (1984) A manual of chemical and biological methods for seawater analysis. Pergamon Press, Oxford

Pomeroy LR, Wiebe WJ (2001) Temperature and substrates as interactive limiting factors for marine heterotrophic bacteria. Aquat Microb Ecol 23:187-204

Porter KG, Feig YS (1980) The use of DAPI for identifying and counting microflora. Limnol Oceanogr 25:943-948

Raymond PA, Bauer JE (2000) Bacterial consumption of DOC during transport through a temperate estuary. Aquat Microb Ecol 22:1-12

Rice WR (1989) Analyzing tables of statistical tests. Evolution 43:223-225

Sala MM, Karner M, Marrasé C (2001) Measurement of ectoenzyme activities as an indication of inorganic nutrient imbalances in microbial communities. Aquat Microb Ecol 23:301-311 
Sañudo-Wilhelmy SA, Taylor GT (1999) Bacterioplankton dynamics and organic carbon partitioning in the lower Hudson River estuary. Mar Ecol Prog Ser 182:17-27

Sharp JH, Benner R, Bennett L, Carlson CA, Fitzwater SE, Peltzer ET, Tupas LM (1995) Analyses of dissolved organic carbon in seawater: The JGOFS EQPAC methods comparisons. Mar Chem 48:91-108

Shiah FK, Gong GC, Chen TY, Chen CC (2000) Temperature dependence of bacterial specific growth rates on the continental shelf of the East China Sea and its potential application in estimating bacterial production. Aquat Microb Ecol 22:155-162

Sinsabaugh RL, Findlay S, Franchini P, Fischer D (1997) Enzymatic analysis of riverine bacterioplankton production. Limnol Oceanogr 42:29-38

Smith SV, Mackenzie FT (1987) The ocean as a net heterotrophic system: implications from the carbon biogeochemical cycle. Global Biogeochem Cycles 1:187-198

Somville M (1984) Measurement and study of substrate specificity of exoglucosidase activity in eutrophic waters. Appl Environ Microbiol 48:1181-1185

Suida W, Chróst RJ (1987) The relationship between alkalinephosphatase (APA) activity and phosphate availability for phytoplankton and bacteria in eutrophic lakes. Acta Microbiol Polonica 36:247-257

Tantichodok P (1990) Relative importance of phytoplankton and organic detritus for the suspension feeding bivalve, Mytilus edulis L. in Long Island Sound. PhD dissertation, State University of New York, Stony Brook, NY

Taylor GT, Way J, Scranton MI (2003) Planktonic carbon

Editorial responsibility: Otto Kinne (Editor),

Oldendorf/Luhe, Germany cycling and transport in surface waters of the highly urbanized Hudson River estuary. Limnol Oceanogr 48: 1779-1795

Tranvik LJ (1990) Bacterioplankton growth on fractions of dissolved organic carbon of different molecular weight from humic and clear waters. Appl Environ Microbiol 56: 1672-1677

Turekian KK, Tanaka N, Turekian VC, Torgersen T, DeAngelo EC (1996) Transfer rates of dissolved tracers through estuaries based on ${ }^{228} \mathrm{Ra}$ : a study in Long Island Sound. Cont Shelf Res 16:863-873

Turley CM, Hughes DJ (1994) The effect of storage temperature on the enumeration of epifluorescence-detectable bacterial cells in preserved sea-water samples. J Mar Biol Assoc UK 74:259-262

Way J (2000) Patterns of bacterioplankton exoenzyme activity in the lower Hudson River and western Long Island Sound estuaries. Master's thesis, State University of New York, Stony Brook, NY

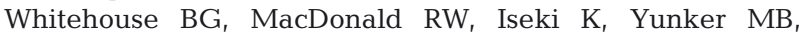
McLaughlin FA (1989) Organic carbon and colloids in the Mackenzie River and Beaufort Sea. Mar Chem 26: 371-378

Wright RT, Hobbie JE (1966) Use of glucose and acetate by bacteria and algae in aquatic ecosystems. Ecology 47: 447-463

Yu Y (1999) Bacterial turnover of selected low molecular weight organic molecules in Hudson River and Long Island Sound estuaries. MS thesis, Stony Brook University, Stony Brook, NY

Submitted: October 4, 2002; Accepted: October 11, 2003

Proofs received from author(s): October 30, 2003 